\title{
De escravo a modelo educacional: a trajetória do pedagogo grego
}

From slave to educational model: the trajectory of the Greek pedagogue

De esclavo a modelo educativo: la trayectoria del pedagogo griego

\author{
Milton Luiz Torres \\ Centro Universitário Adventista de São Paulo (Brasil) \\ http://orcid.org/0000-0003-1158-4876 \\ http://lattes.cnpq.br/6112555912323663 \\ milton.torres@unasp.edu.br
}

\section{Resumo}

Este artigo faz um retrospecto da condição servil do antigo pedagogo grego e discute, com base no Filógelo, um livro de anedotas do séc. IV e V A.D., e em Paladas de Alexandria, um poeta do séc. IV A.D., se ocorreu, de fato, uma transição no estatuto social e econômico do pedagogo que o colocou, a partir do séc. II A.D., como modelo educacional da paideia greco-romana.

Palavras-chave: Pedagogo; Filógelo; Paladas de Alexandria. 


\begin{abstract}
This article analyzes the servile condition of the ancient Greek pedagogue and discusses, based on the Philogelus, an anecdote book from the IV and V century A.D., and Paladas of Alexandria, a poet of the IV century A.D., if there was indeed a transition in the social and economic status of the pedagogue that placed him, starting in the II century A.D., as a model for Greco-Roman education.
\end{abstract}

Keywords: Pedagogue; Philogelus; Paladas of Alexandria.

\title{
Resumen
}

Este artículo analiza la condición servil del antiguo pedagogo griego y discute, basado en el Philogelus, un libro de anécdotas del IV y V siglo A.D., y Paladas de Alejandría, el poeta del siglo IV A.D., si efectivamente se produjo una transición en la situación social y económica del pedagogo que lo colocó, a partir del siglo II A.D., como modelo educativo de la paideia grecorromana.

Palabras-clave: Pedagogo; Philogelus; Paladas de Alejandría. 


\title{
Introdução
}

Com sua comédia teatral e propensão natural para a troça, pode-se dizer que os antigos gregos praticamente inventaram o humor. $\mathrm{O}$ deboche tem a inconveniência de exagerar os fatos; em raras ocasiões, porém, consuma uma mentira deslavada. E talvez seja nesse local aparentemente pouco provável que encontremos algum auxílio para a solução de um instigante mistério na história da educação. Ainda não se compreende, de forma inequívoca, como e quando se deu a metamorfose que transformou o pedagogo, escravo que acompanhava as crianças gregas à escola ou à casa do professor, no modelo educacional que o Ocidente devia seguir. Ao tratar da obra O pedagogo, escrita por Clemente de Alexandria no séc. II A.D., Jaeger (1991, p. 83-84) opina que, nesse momento da história, a transição já estava completa. Segundo ele,

\begin{abstract}
A própria escolha do título Paedagogus, que mostra Cristo num novo papel [...] como o "educador da humanidade", é posta por esse meio em contraste com a ideia grega de cultura no seu todo, pois é esse o sentido exato que a palavra paideia desenvolveu no decurso da sua história. O emprego da palavra "pedagogo" neste sentido exaltado indica que ela já não significava o escravo que, nos séculos clássicos da Grécia, costumava acompanhar um jovem à escola e desta para casa, mas está mais próxima do sentido filosófico que Platão dava à palavra paidogogein nas Leis, em que define a relação de Deus com o mundo deste modo: "Deus é o pedagogo do mundo inteiro".
\end{abstract}

Jaeger exagerou. Platão não estava atribuindo a Deus o papel de pedagogo nem tampouco vislumbrando essa função como uma nobre carreira a ser seguida pelos educadores de sua época. Basta, aqui, a inclusão da citação platônica (Leis 897b) em seu contexto para que se perceba isso:

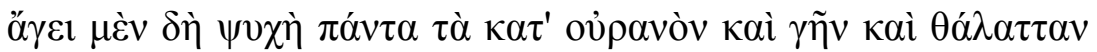

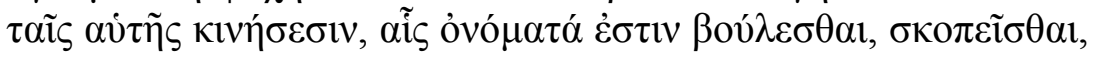

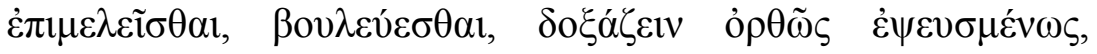

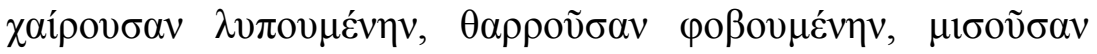

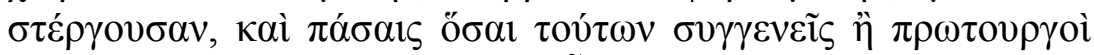

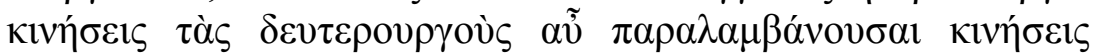

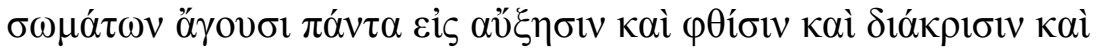

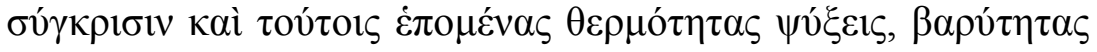

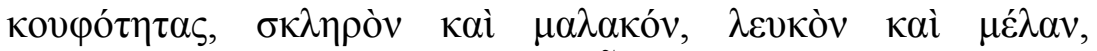

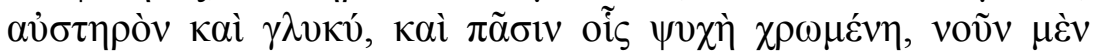

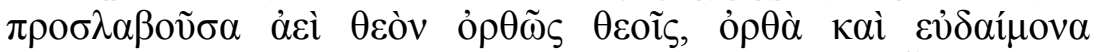

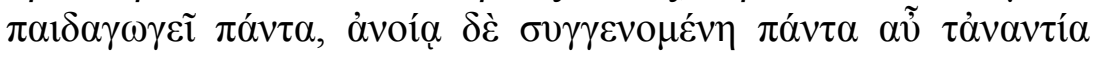

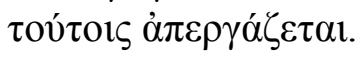

a alma direciona, então, todas as coisas no céu, na terra e no mar com seus movimentos, cujos nomes são querer, investigar, cuidar, deliberar e opinar correta ou falsamente. Ela faz isso quando exulta e lamenta, atreve-se e teme, odeia e ama, e todas as outras ações com estas relacionadas. Ou os movimentos primários recebendo, de novo, os movimentos secundários das 
substâncias corpóreas, direcionam todas as coisas para o crescimento e a corrupção, para a decomposição e a composição, e para as coisas que as acompanham, como as quentes e as frias, as pesadas e as leves, o que é duro e o que é macio, o branco e o preto, o amargo e o doce, e todas as outras coisas divinas que a alma usa, pois quando esta aceita a razão, ela mesma considerada corretamente como deusa, a alma corretamente leva [paidagôgei] todas as coisas para a felicidade; quando, porém, ela se associa com a tolice, ela realiza o contrário de tudo isso.

Ou seja, a evidência aduzida por Jaeger para amparar a ideia de que o pedagogo tinha uma estirpe ilustre afinal das contas, não se sustenta.

De acordo com Quinn (2001), os livros de piada vêm de uma longa história na tradição oral, sendo que, em Ateneu 614d-e, menciona-se que Filipe da Macedônia, pai de Alexandre, o Grande, encomendou de Atenas uma obra assim e pagou caro por ela. De fato, no séc. II a.C., Plauto menciona, por duas vezes, a existência desses livros, em Persa 392 e Stichus 400. O que parece é que tais livros forneciam o repertório de piadas empregadas pelos parasitas no contexto dos banquetes ou na barbearia, lugar tradicional da fofoca masculina. O Suda, uma espécie de enciclopédia grega da era

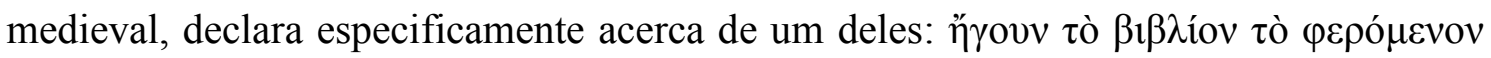

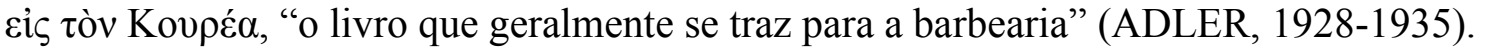

Já que a escola foi o objeto de algumas anedotas gregas do período cristão, o que será que essas facécias despretensiosas podem nos revelar sobre a figura do pedagogo no final da Antiguidade? Será que elas sugerem, como quer Jaeger, que a transição para um estatuto elevado já tinha ocorrido? Que aspectos peculiares da vida escolar revelam? Eu me refiro à obra Filógelo (THIERFELDER, 1968), um texto grego do séc. IV ou V, que os manuscritos geralmente atribuem aos compiladores Hiérocles, um filósofo neoplatônico, e Filágrio, o sofista. O título, que pode ser traduzido como "viciado em riso" ou "amante da risada", revela a natureza de seu conteúdo: trata-se do mais antigo livro de piadas a nos chegar da era greco-romana. O compêndio, famoso por sua escassez das piadas ditas "sujas", inclui uma coleção de 265 anedotas sobre os mais variados temas e personagens, cerca de dez das quais versam sobre a escola e o pedagogo. Jennings (2001), ao comentar sobre a nova edição e tradução do Filógelo por Dawe (2000), sugere que o estudo de anedotas pode incrementar nossa compreensão dos estereótipos da Antiguidade.

As anedotas do Filógelo são curtas e ao ponto. Parecem conservar apenas o teor geral de uma ideia que o piadista deve adaptar a seus modos e objetivos, tornando-a mais gráfica e atrativa. Seu principal objeto de riso é o scholastikos, personagem típico (stock character) imortalizado pelas antigas comédias áticas (TORRES, 2014). Trata-se, em geral, de um erudito pedante. No entanto, para Andreassi (2004, p. 43-51), nessa época o termo já tinha perdido esse sentido bastante técnico e simplesmente assinalava que o ouvinte estava diante de uma anedota, assim como as crianças sabem, hoje, que estão diante de um conto de fadas quando ouvem a expressão "era uma vez". Por essa razão, Crompton (2013) geralmente traduz essa fórmula como "um idiota". Das dez anedotas selecionadas para análise aqui, apenas duas incluem o pedagogo. As outras falam de alunos e professores ou fazem menção, de alguma forma, à vida escolar. 


\section{Piadas sobre um aluno que morre}

Um grupo especialmente interessante de piadas do Filógelo inclui três anedotas $(77,257$ e 258$)$ em que o aluno morre e, por essa razão, não comparece à escola. Na anedota 77, um pai se desculpa com o professor pela ausência do filho morto:

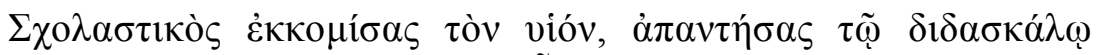

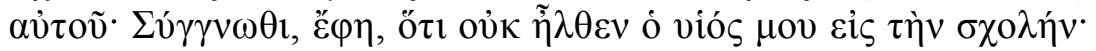

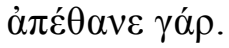

Um idiota acompanhava o féretro do filho quando se encontrou por acaso com o professor dele e disse: - Por favor, desculpe por meu filho não ter ido à aula: ele faleceu!

De gosto não se discute, mas o conteúdo da piada talvez soe mórbido demais para nossa refinada preferência. Trata-se quase de um exemplo de humor negro. O "idiota" (scholastikos) não está oferecendo uma desculpa esfarrapada pela ausência do filho. O uso do verbo ekkomizô revela, de fato, a ocorrência de um cortejo fúnebre e mostra a verdade da fala do pai ansioso. O que causa graça é sua preocupação em justificar, para o "professor" (didaskalos), a ausência do filho falecido. O vocábulo scholê, traduzido por "aula", significa também "escola". Tecnicamente, significa mesmo "lazer" ou "ócio". Se não fosse pela abreviação, a ideia de "escola" deveria ser evocada pelo termo scholastêrion, isto é, "lugar de ócio". A presença de scholê na anedota aponta, em primeiro lugar, para a íntima associação entre o homem pedante e ocioso (scholastikos) com o ambiente escolar. Em segundo lugar, sugere que a escola não era vista, na Antiguidade, como um lugar de tédio e maçantes exercícios intelectuais, mas um espaço para o prazer. Por isso, pergunta-se: mudamos nós ou mudou a escola?

A anedota 257, em que pese seu mau gosto, demonstra a mesma ansiedade em relação à frequência das crianças à aula:

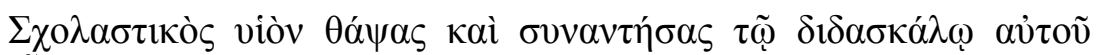

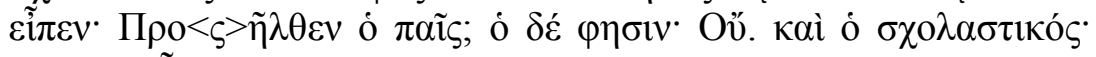

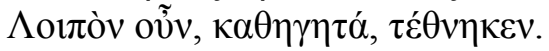

Após sepultar o filho, um idiota se deparou por acaso com o mestre dele e perguntou: - Compareceu o menino? Ele respondeu: - Não. Ao que disse o idiota: - Bem, chefe, é que ele faleceu!

O humor, aqui, certamente não deriva da pergunta absurda do pai, mas do fato de que, até nos piores momentos, o pai ainda se preocupava com a apreciação do professor em relação à ausência do filho às atividades escolares do dia. $\mathrm{Na}$ anedota, o pai usa duas palavras distintas para se referir ao educador: os termos "mestre" (didaskalos) e "chefe" (kathêgêtês), ambos tão respeitosos, que são usados, também nos evangelhos, em referência a Cristo (Mateus 8:19 e 23:10, por exemplo). A anedota $\underline{\mathbf{2 5 8}}$ é um pouco mais longa e elaborada:

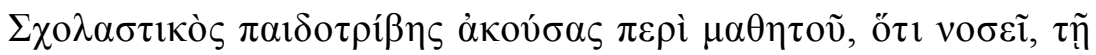

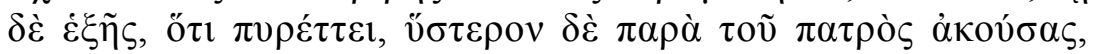

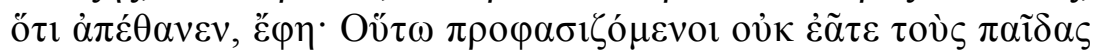
$\mu \alpha v \theta \alpha \dot{v \varepsilon ı v}$. 
Quando um professor de educação física idiótico ouviu um pai falar que um aluno estava doente; logo em seguida, que estava com febre; e, por último, que havia morrido, disse: - Arranjando tantas desculpas assim, vocês não estão deixando os filhos aprenderem.

Esta anedota difere das anteriores porque, neste caso, não temos inteira certeza se as justificativas procedem. Pelo menos aos olhos do professor idiótico, o paidotribês, espécie de personal trainer da Antiguidade, que acompanhava os exercícios físicos dos "alunos" (mathêtai) nos ginásios gregos, os pais costumavam mentir descaradamente para proteger os filhos. Apesar disso, a evolução do quadro da criança indica que, neste caso, o pai dizia a verdade.

As anedotas sobre a morte de um aluno sugerem que a falta às atividades escolares era considerada algo tão grave que exigia a justificativa por parte dos pais. Mostram também que o comparecimento do aluno à aula era uma constante preocupação de pais e mestres.

\section{Piadas sobre o professor incompetente}

O Filógelo contém um grupo de piadas em que se debocha da falta de talento de alguns professores. Assim, a anedota 140 nos remete a uma situação desagradável no ensino das primeiras letras:

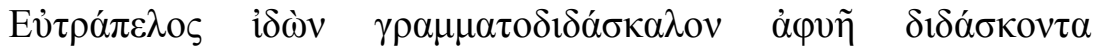

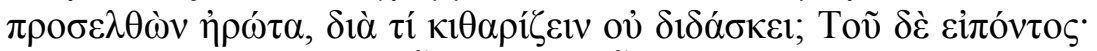

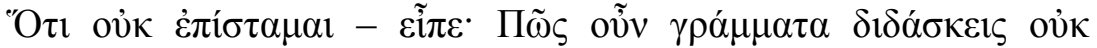
$\dot{\varepsilon} \pi \imath \tau \alpha \dot{\mu} \mu \varepsilon \vee \circ$;

Um gozador viu um alfabetizador sem talento dando aulas, aproximou-se e perguntou: por que você não dá aulas de cítara? Este respondeu: - Porque não sei! Como, então, você ensina as letras sem saber?

"Um gozador viu" (eutrapêlos idôn) é uma fórmula que inicia três anedotas (140, 147 e 151) no Filógelo. Na anedota 140, o "gozador" vê "um professor sem talento" (grammatodidaskalon aphyê). Trata-se de um professor de alfabetização (grammatodidaskalos) que trabalha contra sua natureza ou inclinação natural, o que é indicado pelo adjetivo aphyês, que tem precisamente esse sentido, embora Crompton (2013, p. 94) prefira chamá-lo de "aprendiz de professor". Diante dessa visão desanimadora, o "gozador" sugere que ele ensine cítara (kitharizein), uma prática em que sua impostura logo se tornaria evidente. Isso faz lembrar o relato de Xenofonte, em Lembrança de Sócrates 1.7.1-2 (MARCHANT, 1921), em que o autor argumenta que Sócrates alegava que o que se faz passar por flautista deve imitar um flautista genuíno em todos os aspectos, exceto um: jamais deve concordar em apresentar um solo de flauta. No momento em que fizesse isso, seria desmascarado. Até um simples "professor de letras" sabe disso e, por essa razão, se exime de ensinar cítara, flauta ou qualquer outro instrumento musical. No entanto, muita gente pensa que, na escola, qualquer um pode ser professor. Daí, a contundente fala final do "gozador": "como, então, você ensina letras sem saber?” Não espanta que essa pergunta soe tão atual? 
Na anedota 196, o professor pode não ter talento, mas tem presença de espírito:

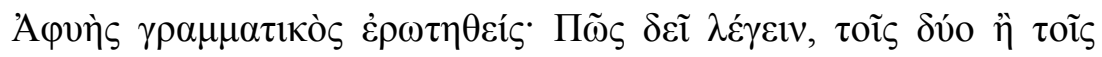

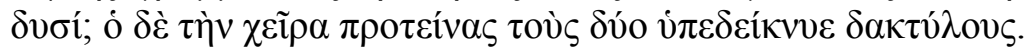

Perguntaram a certo professor de gramática sem talento: - O certo é dizer dois ou ambos? Este estendeu, porém, a mão e mostrou dois dedos.

A dúvida gramatical de quem faz a pergunta tem que ver com a declinação dos numerais. Deseja-se saber se o numeral "dois" (dyo) deve ser declinado para acompanhar o caso do artigo ou não. Seria impossível reproduzir exatamente essa indagação no português, que é uma língua em que não existem declinações. Mesmo assim, a alternância entre "dois" e "ambos" é conveniente porque essas expressões têm proximidade suficiente para imitar a relação íntima que se percebe entre o caso nominativo do numeral $(d y o)$ e seu caso dativo (dysi). Infelizmente, entretanto, a pergunta da anedota, no português, não tem uma resposta gramaticalmente correta e depende do contexto de uso dessas palavras, enquanto que, em grego, a resposta correta seria tois dysi (e não tois dyo), pois o numeral "dois" deveria sim acompanhar a declinação do artigo. Ainda assim, tanto na anedota em grego quanto na piada em português, o "professor de gramática" (grammatikos) se exime de responder a indagação, uma vez que a exibição dos dois dedos pode ser interpretada como ambígua. Ainda bem, no entanto, que ele não mostrou um dedo apenas! Na anedota 197, temos uma piada sobre a aula de literatura:

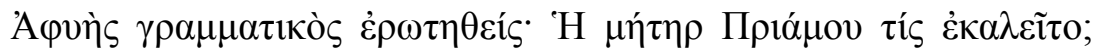

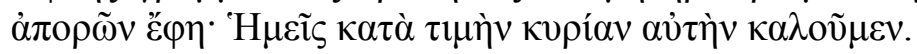

Perguntaram a um professor de gramática sem talento como se chamava a mãe de Príamo. Vendo-se em apuros, ele respondeu: - É mais educado chamá-la de "senhora".

O verbo "estar em apuros" (aporeô) aparece, com frequência, nos diálogos platônicos, quando Sócrates aperta um de seus interlocutores e o deixa sem resposta para suas perguntas incisivas. É compreensível, porém, que o professor se sentisse em apuros, já que essa "senhora" (kyria), a quem Héracles matou e que era casada com Príamo, rei de Troia, não apenas é uma figura obscura na literatura épica, mas recebe, além disso, vários nomes. Escamão (MÜLLER, 1851), historiador grego do séc. IV a.C., filho do historiador Helânico, ao comentar, no fragmento 6.1, a passagem da Ilíada (3.250), em que Príamo é chamado de "filho de Laomedonte" (Laomedontiadês), afirma que Porfírio, em uma obra perdida intitulada Nomes omitidos por Homero, a chama por esse nome; enquanto que Alcman a chama de Leuxipe; Helânico, de Estimo; e Estâmis, de Toasa. Hécuba, esposa de Príamo, também tinha mãe pouco conhecida (FOWLER, 2013, v. 2, p. 527). De fato, de acordo com Suetônio (Tibério 70.3), o imperador Tibério costumava selecionar seus professores indagando-lhes quem seria a mãe de Hécuba. Só os que corretamente respondiam Evágore (cf. Hesíodo, Teogonia 257), eram contratados. Se o professor da piada não sabia quem era a mãe de Príamo, tampouco saberia quem era sua sogra! Não seria, portanto, contratado. A anedota aponta, então, para a importância que a literatura grega continuava a ter, mesmo numa época em que o cristianismo já havia se estabelecido como religião oficial do império. 


\section{Piadas sobre o aluno incompetente}

Há também, no Filógelo, algumas piadas sobre o aluno incompetente. $\mathrm{Na}$ anedota 199, o rapaz se vê em dificuldades enquanto os colegas se paramentam provavelmente para os exercícios na aula de educação física:

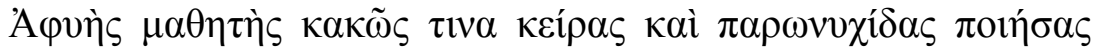

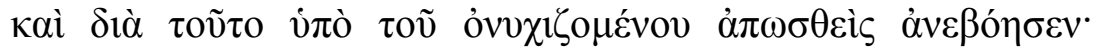

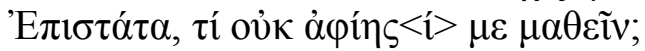

Um aluno incompetente corta muito mal o cabelo e faz um unheiro no outro. Por essa razão, é empurrado por aquele cujas unhas haviam sido aparadas e grita: - Treinador, por que ele não me deixa aprender?

O fato de o aluno chamar o professor de "treinador" (epistatês) sugere o contexto do ginásio. Apesar disso, a palavra tem também o sentido de "supervisor" e, por isso, pode ambientar o episódio na própria sala de aula. $\mathrm{O}$ aluno corta as unhas de seu colega no sabugo. $\mathrm{O}$ uso da expressão parônychidas poiêsas sugere que o aluno fez panarício ou unheiro, ferindo, portanto, a pessoa em quem praticava. A graça da piada reside no fato de o aluno incompetente estranhar a atitude de sua vítima, exigindo do treinador uma oportunidade de aprender.

Parece que a questão de aprender a aparar as unhas era uma parte importante do currículo, já que a anedota 200 versa sobre o mesmo tema:

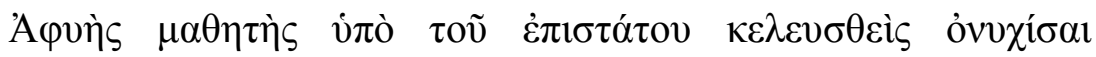

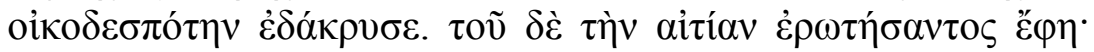

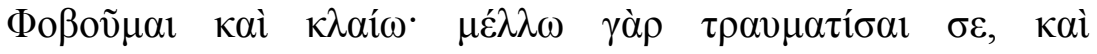

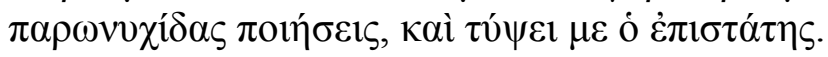

Um aluno incompetente chorou quando o treinador mandou que cortasse as unhas de certo senhor. Quando este lhe perguntou a razão, ele respondeu: - Estou chorando porque tenho medo. Eu vou machucar você; eu vou fazer um unheiro, e o treinador vai me bater.

As anedotas sobre a incompetência de alunos e professores mostram que a vocação para o ensino e o aprendizado sempre foram relativas, contingentes a interesses pessoais, disposição e habilidades naturais. A anedota 200 fala também da realidade da punição física em caso de desempenho insatisfatório.

\section{Anedotas sobre a vida escolar}

Outro grupo de piadas do Filógelo sobre a vida escolar não se reduz a uma temática específica. A anedota $\mathbf{6 1}$ tem o seguinte teor:

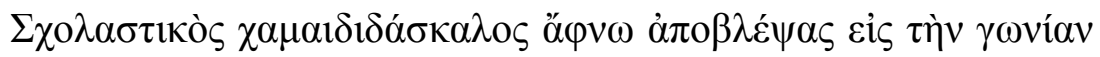

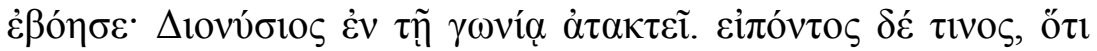

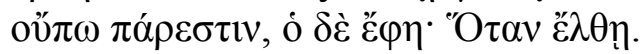


Um idiótico professor primário olha, de repente, para o canto e grita: Dionísio está reinando no canto! Quando dizem que ele ainda não está presente, o professor fala: - Ele decerto vai reinar quando chegar!

Nesta anedota, nota-se que o educador é identificado como "professor primário" (chamaididaskalos). O termo significa, literalmente, "aquele que ensina no chão", uma provável referência ao fato de que esse professor lida com crianças pequenas que ainda se voltam mais para atividades lúdicas do que para o aprendizado de conteúdos propriamente ditos. Esse professor é o objeto da piada; por isso, sua identificação como "idiótico" (scholastikos). O mestre deseja disciplinar um aluno chamado Dionísio, aliás um nome perfeito para as intenções do piadista, uma vez que faz referência ao deus da embriaguez e da vida desregrada. O professor reclama que Dionísio está "reinando" num canto da sala. O verbo atakteô, traduzido por "reinar", significa "suscitar uma rebelião", "agir subversivamente" ou "levar uma vida desordenada". O vocábulo parece dramático demais para a situação e revela a natureza pedante da fala do professor. Apesar de o professor desejar repreender o aluno, esbarra no fato de que o menino ainda não estava presente. Daí a graça da facécia.

A anedota 61 revela que, como hoje, os professores enfrentavam, na Antiguidade tardia, o mau comportamento de alguns alunos insubordinados e difíceis de engajar no processo educativo. $\mathrm{Na}$ anedota 136 , o contexto tem que ver mais com estereótipos:

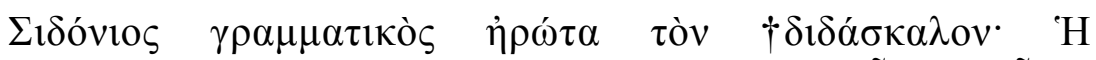

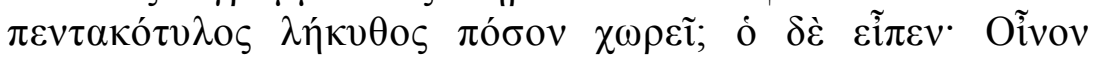

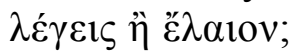

Um professor de gramática de Sidon perguntou ao mestre: Quantos litros cabem no frasco de um litro? Este responde: de vinho ou de azeite?

O Filógelo inclui várias anedotas sobre os sidônios, isto é, os habitantes de Sidon, uma das cidades da Fenícia. De fato, o Suda nos informa que os antigos gregos costumavam se referir a qualquer fenício como "sidônio". Como objeto das gozações em relação aos sidônios podemos listar, a título de exemplo: o "orador" (rhêtôr) da anedota 129, o "sofista" (sophistês) das anedotas 130 e 131, o "homem de negócios" (pragmateutês) da anedota 133, o "centurião" (hekatontarchos ou kentouriôn) das anedotas 134 e 138, e o médico (iatros) da anedota 139. Como se percebe, há toda uma seção dedicada às idiotices praticadas por esses estrangeiros cuja inteligência os gregos subestimavam. No caso da anedota 136, o sidônio é um professor primário (grammatikos). O termo grego, de onde se originou a palavra "gramática" em português, faz referência ao ensino das primeiras letras (grammata). Trata-se, portanto, de uma espécie de "alfabetizador". Ele engaja outro professor na conversa, que gozava, evidentemente, de estatuto superior. Este não vem de Sidon e é identificado pelo pomposo título de "mestre" (didaskalos). O frasco em questão é o lêkythos, uma vasilha geralmente destinada a conter perfumes e unguentos. A medida empregada é a kotylê, equivalente a um quarto de litro. Cinco kotylai totalizam 1,25 litros. A pergunta do sidônio é suficientemente idiota para suscitar alguns bons risos; numa reversão cômica, porém, o próprio mestre se revela igualmente estulto. No final das contas, aquele que é o objeto da estereotipização não é muito diferente do pedante mestre grego com quem dialoga, a não ser que imaginemos que sejam ambos sidônios e que sua atuação ocorra 
numa escola de Sidon, mas isso não fica explícito na anedota. O termo scholastikos não aparece aqui em referência a nenhum dos dois personagens, o que sugere que, potencialmente, ambos se tornam o foco da pilhéria. De qualquer forma, a piada revela que, mesmo no berço da educação, já havia a estratificação que, até hoje, faz com que alguns educadores se subordinem a outros.

\section{Piadas sobre o pedagogo}

Nas anedotas tratadas até aqui, não encontramos nenhuma referência ao pedagogo. Deixamos para esta última seção as poucas piadas que lidam com essa figura enigmática. Em geral, são situações relacionadas à comida ou bebida. Na anedota 79, o assunto é o vinho:

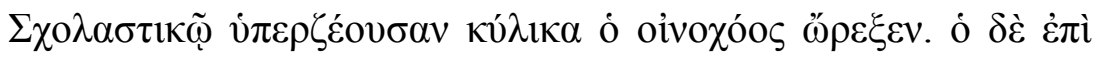

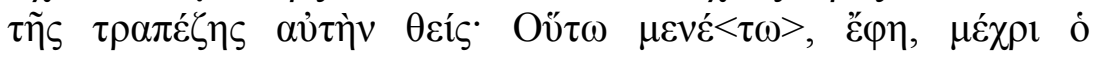

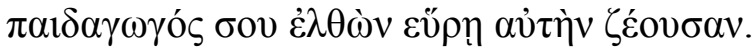

Um copeiro enche uma taça até a boca e a estende para um rapaz com cara de idiota. Ele a coloca sobre a mesa, e o copeiro ordena: - Deixe-a ficar aí até que seu pedagogo venha e a encontre cheia.

O costume era que o "pedagogo" (paidagôgos) acompanhasse seus pupilos ao destino, deixasse-os lá e voltasse, depois, para buscá-los. Na Antiguidade grega, o vinho era diluído em água. Para embebedar-se, o conviva precisava de uma grande quantidade da bebida. Neste caso, porém, o copeiro explicitamente exige que o rapaz não beba. A "taça transbordante" (hyperzeousan kylika) não deve ser esvaziada até a volta do acompanhante. A piada nos ajuda a perceber que, no final da Antiguidade, entre os séc. IV e V A.D., o pedagogo ainda retinha sua função tradicional de acompanhante.

No Filógelo, há algumas anedotas sobre pessoas esfaimadas. Na anedota 221, é um "médico" (iatros) que se encontra faminto; na 222, é um "paciente" (arrôstos); na 226, é um "ator" (hypokritês); nas anedotas 219 e 223-225, é uma pessoa qualquer. Geralmente, alguém acaba de assar um pedaço de pão e colocá-lo para esfriar em um lugar onde ele fica armazenado com segurança, longe do alcance de animais selvagens, mas também onde nossos personagens famintos conseguem, ainda assim, vê-lo. Na anedota 223, um homem faminto vê um pedaço de pão suspenso no "umbral da porta" (hypertyros). Na anedota 221, por sua vez, um médico faminto vê o pão esfriando em um "buraco" (trypê)

A piada que nos interessa mais especificamente é a anedota 220, na qual se debocha da fome de um pedagogo. É comum, no Filógelo, que a mesma piada tenha duas versões e isso ocorre com a anedota do pedagogo. Na primeira versão dessa piada, o nome do pedagogo é substituído por uma referência ao "professor de ginástica" (paidotribês).

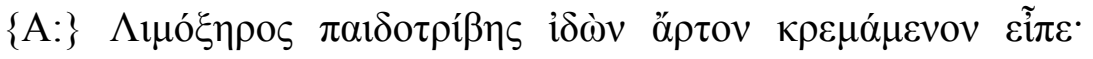

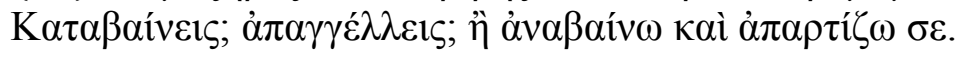

\{A:\} Um faminto professor de ginástica viu um pão suspenso e disse: - Vais descer? Prometes? Ou devo subir para ficar no teu nível? 
Movido pelo apetite, o professor de ginástica da piada 220 inicia um diálogo com o objeto de seu desejo. Na conversa, procura seduzir o pão para que este venha ao seu encontro. Caso isso não aconteça, fica patente a ameaça de que o faminto subirá ao seu encontro. De uma forma ou de outra, o pão alheio acabará comido. Na segunda versão da anedota 220, aparece o pedagogo em vez do professor de ginástica:

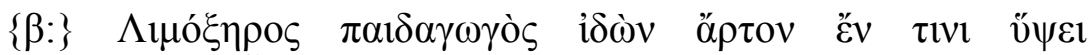

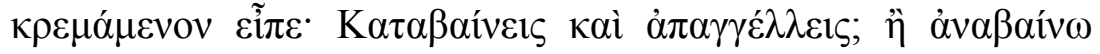 \\ $<\kappa \alpha i>\dot{\alpha} \pi \alpha \rho \tau i \zeta \omega \sigma \varepsilon$.
}

\{B\} Um pedagogo faminto viu um pão suspenso num lugar alto e disse: - Vais descer? Prometes? Ou devo subir e ficar no teu nível?

A alternância entre professor de ginástica, médico, ator, pedagogo e algumas pessoas comuns, cuja profissão não é revelada, demonstra a condição servil de todos esses personagens, inclusive do médico (TORRES, 2008, p. 179-181). Nesse grupo de anedotas, personagens esfaimados querem furtar um pedaço de pão alheio, e o fazem para saciar a fome. Não podem ser, evidentemente, aristocratas.

\title{
Conclusão
}

O exame de algumas anedotas sobre o pedagogo e a vida escolar no séc. IV ou V A.D. não revela que tenha ocorrido algum tipo de transição na condição social do pedagogo nem na apreciação que dele se tinha na sociedade greco-romana. O pedagogo começa a carreira como escravo e, até esse momento na história, continua a gozar de uma condição social desfavorável. Por essa razão, não se pode pretender que sua escolha para representar a arte e a ciência da educação de jovens e crianças tenha se originado de um maior estatuto social que lhe teria sido conferido pelo crescimento do cristianismo. Gostaria, portanto, de sugerir que, ao contrário disso, sua escolha se deveu principalmente ao fato de que esse estatuto social tenha sido pouco ou minimamente inferior àquele de que os próprios professores desfrutaram na Antiguidade tardia. Não me refiro aqui aos grandes mestres e filósofos, sob cuja responsabilidade estava a educação das crianças da alta aristocracia, mas aos professores que quotidianamente se ocupavam da educação de crianças e jovens de estatuto menos elevado. Paladas de Alexandria, por exemplo, foi um poeta do séc. IV A.D. que se dedicou justamente a essa carreira. Seus poemas fazem parte da assim-chamada Antologia grega, uma coleção de mais de seis mil poemas escritos por cerca de 300 poetas diferentes durante um período de mais de mil anos (PATON, 1916-1918). Dotado de um senso de humor notável, o poeta afirma o seguinte, no epigrama 72 do livro 10 :

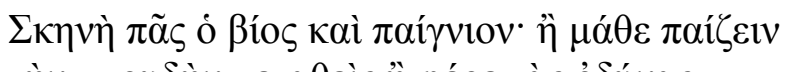

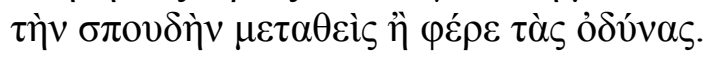

A vida é toda palco e comédia;

Quem não aprende a brincar, paga a conta.

Por causa dessa filosofia de vida, no epigrama 169 do livro 9, Paladas se refere, de forma bem-humorada, às dificuldades financeiras que enfrentava como professor de gramática, razão pela qual ele considera a profissão como um voto de pobreza: 


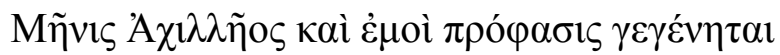

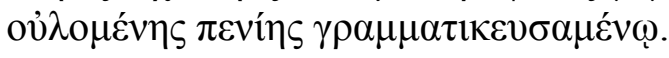

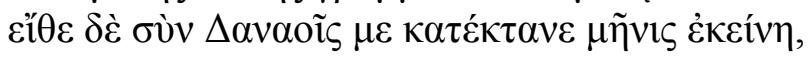

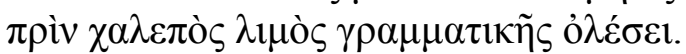

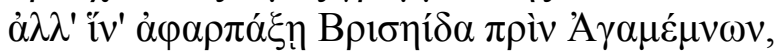

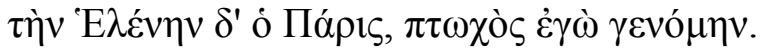

A cólera de Aquiles foi motivo também para mim,

De nefasta pobreza ao ensinar gramática.

Quem dera com os gregos me matasse aquela cólera,

Antes que me abatesse a penosa fome de gramática.

Porém, para que Agamenão raptasse Briseida

E Páris, Helena, foi que me fiz indigente.

Sendo assim, no epigrama 171 do livro 9, decide abandonar a carreira de professor em busca de uma melhor condição:

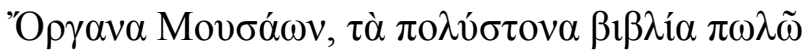

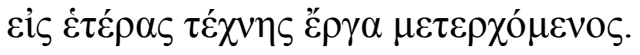

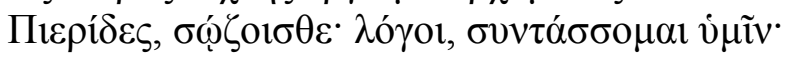

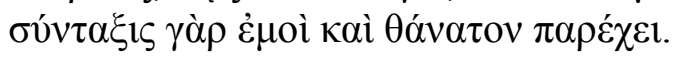

Estou vendendo os meus livrinhos pesarosos, essas peças de museu,

Pois estou mudando para as obras de outro ofício.

Musas, adeus! Letras, dou-lhes um tiauzinho!

É que a análise sintática só me traz a morte.

O poeta põe à venda os seus "livrinhos pesarosos" (ta polystona bíblia), aos quais se refere como sendo "peças de museu", isto é, "instrumentos das musas" (organa mousaôn). Certamente, demandou muito esforço até que dominasse os pormenores literários e gramaticais da paideia, a antiga educação grega. Apesar do empenho exigido, a recompensa não vem à altura. Então, despede-se das "musas" (pierides) e das "letras" (logoi), em busca agora de "outro ofício" (heteras technês). Sua conclusão é que ocupar-se da sintaxe não era suficiente para lhe proporcionar o estilo de vida que almejava.

Parece, portanto, que a condição quase servil dos professores da era grecoromana é que fez com que o pedagogo, escravo encarregado de acompanhar as crianças e jovens à escola e a outros lugares de seu interesse, se identificasse com os professores e emprestasse seu nome à arte de educar. Embora seja uma triste constatação, esta posição sugere que o magistério tem sido tradicionalmente menosprezado, o que implica que se trata mesmo de aprendermos a reconhecer a importância do pedagogo e sua formidável contribuição para a formação das pessoas, a despeito de seu próprio desconforto social e econômico.

À parte das considerações mais prementes e imediatas aqui tecidas, a relação entre filosofia, ironia e pedagogia remete-nos para o fato de que "a dimensão pedagógica da ironia" contribui para o desenvolvimento de um "processo ascendente" em que "a dimensão crítico-emancipatória da ironia se afirma como hegemônica nas relações dialógicas entre os agentes educacionais" (ZUIN, 2008, p. 14). De fato, a origem servil do pedagogo e sua trajetória milenar podem inspirá-lo, por causa de sua 
dimensão intrinsecamente filosófica e irônica, a não apresentar aos alunos um ensino além de qualquer questionamento, conforme sugerido pela própria conotação do termo "ironia" após Sócrates lhe conceder o sentido positivo de "estímulo à elaboração de novos significados" (ZUIN, 2008, p. 17), o que significa que não há pedestal no qual o professor possa se estribar. E isso indicam tanto sua origem histórica quanto a postura necessariamente filosófica e irônica que a educação lhe exige.

\section{Referências}

ADLER, A. (Ed.). Suidae lexicon. Leipzig: Teubner, 1928-1935. 4 v.

ANDREASSI, M. Le facezie del Philogelos: barzellette antiche e umorismo moderno. Lecce: P. Multimedia, 2004.

CROMPTON, Dan. A funny thing happened on the way to the forum: the world's oldest joke book. London: Michael O’Mara, 2013.

DAWE, R. D. Philogelos. München/Leipzig: K. G. Saur, 2000.

FOWLER, Robert L. Early Greek mythography. Oxford: OUP, 2013. v. 2.

JAEGER, W. Cristianismo primitivo e paideia grega. Tradução de Teresa Loureuri Perez. Lisboa: Edições 70, 1991.

JENNINGS, Victoria. Review of R. D. Dawe, Philogelos. Bryn Mawr Classical Review, 2001.04.05. Disponível em: http://bmcr.brynmawr.edu/2001/2001-04-05.html. Acesso em: 14 out. 2016.

MARCHANT, E. C. (Ed.). Xenophontis opera omnia. 2. ed. Oxford: Clarendon, 1921. MÜLLER, Carl. (Ed.). Fragmenta historicorum graecorum. Paris: Didot, 1851. v. 4.

PATON, W. R. (Ed.). Greek anthology. Loeb Classical Library. Cambridge: HUP, 1916-1918.

QUINN, John T. 45 jokes from The laughter lover. Diotima, 2001. Disponível em: http://www.stoa.org/diotima/anthology/quinn_jokes.shtml. Acesso em: 14 out. 2016.

THIERFELDER, A. (Ed.). Philogelos der Lachfreund von Hierokles und Philagrios. Munich: Heimeran, 1968.

TORRES, Milton L. Resenha de Textos hipocráticos: o doente, o médico e a doença. Cadernos de Tradução, v.1, n.21, p. 179-181, 2008. https://doi.org/10.5007/2175$\underline{7968.2008 v 1 \mathrm{n} 21 \mathrm{p} 179}$

TORRES, Milton L. A impostura em Aristófanes. Tese de Doutorado em Letras Clássicas. São Paulo, Universidade de São Paulo, 2014. 350f.

ZUIN, Antonio. A dialética socrática como paideia irônica. Revista Brasileira de Estudos Pedagógicos, v. 89, n. 221, p. 11-29, jan./abr. 2008. 